\section{Birlesik Dünya Arastırma New Trends and Issues BD-CENTER Proceedings on Humanities and Innovasyon ve Yayıneılık Merkezi \\ Social Sciences}

Volume 7, Issue 3, (2020) 20-26

\title{
An evaluation of school directors' organisational creativity and managerial effectiveness
}

Timucin Ozkan*, Educational Sciences Institute, Faculty of Education, Cyprus West University, Famagusta, North Cyprus https://orcid.org/0000-0003-4652-0012

Aytac Tokel, Cyprus West University, Educational Sciences Institute, Faculty of Education, Famagusta, North Cyprus https://orcid.org/0000-0002-4079-3573

\section{Suggested Citation:}

Ozkan, T. \& Tokel, A. (2020). An evaluation of school directors' organisational creativity and managerial effectiveness. New Trends and Issues Proceedings on Humanities and Social Sciences. 7(3), pp 20-26.

Received from July 20, 2020; revised from August 15, 2020; accepted from November 25, 2020

Selection and peer review under responsibility of Prof. Dr. Huseyin Uzunboylu, Higher Education Planning, Supervision, Accreditation and Coordination Board, Cyprus.

${ }^{\circ} 2020$ Birlesik Dunya Yenilik Arastirma ve Yayincilik Merkezi. All rights reserved.

\begin{abstract}
Technology is gradually becoming a crucial factor in reaching educational targets. A person undertaking managerial responsibilities should possess managerial efficiency characteristics and exhibit them as well. The critical thinking process exists in all affective and intellectual activities as well as in every study and effort. Creativity is assumed to be a process at the end of which an original product is created. It also includes flexibility, multi-sided thinking, sensitivity, interest in human beings and rationalism. This study was carried out to evaluate secondary school directors' views about their organisational creativity and managerial efficiencies. The aim of this research is to investigate school directors' efficiencies in organisational creativity and management through the specified sub-problems and determine the connection between managerial efficiency and organisational creativity. The research was carried out through the qualitative method, which is based on an interdisciplinary holistic view in interpreting the research question. The facts and events are interpreted in terms of people's understanding. Semi-structured interview questions were used to increase the reliability of the study. Face-to-face interviews were conducted with 18 secondary school directors and assistant directors in a qualitative method. The data were recorded on the computer and then analysed through content analysis, one of the qualitative research techniques. The main aim of content analysis is to reach concepts and connections to help the explanation of the data. Questions written in advance were subjected to content analysis so as to open a way to redo the study. The findings in this research revealed that the directors who supported common decision-making and collaboration exhibited sufficient managerial efficiency. Physical and infrastructure shortages in secondary education cause inequality in education. The most crucial factors in achieving school targets need to be constantly trained in technological, humanitarian and conceptual dimension skills of management science before and after undertaking their positions.
\end{abstract}

* ADDRESS FOR CORRESPONDENCE: Aytac Tokel, Cyprus West University, Educational Sciences Institute, Faculty of Education, Famagusta, North Cyprus.

E-mail address: a.tokel@cwu.edu.tr 
Keywords: School director, organisational creativity, managerial efficiency.

\section{Introduction}

The aim of every community in the world today is to raise active individuals who can do research, create, criticise, participate, adapt innovations, put thoughts into practice and solve problems (Koray \& Cil, 2006, p.56). These overall changes in the world affect education systems and necessitate an overview of educational programmes and develop them to meet the requirements of the century (Zayif, 2008, p. 73). In this regard, it has become of utmost importance that educational programmes include creative and critical thinking concepts to be adapted by individuals. In addition, education systems need to be designed with new methods and programmes encouraging self-learning, selfdevelopment and being scientific more than ever. In this way, the desire for self-development and encouragement is always questioned by both the employer and employees as appealing factors (Kokturk, 2002, p.38).

The critical thinking process exists in all affective and intellectual activities as well as in every study and effort. Creativity is assumed to bea process at the end of which an original product is created (Yenilmez\&Yolcu, 2007, p. 27). It also includes flexibility, multi-sided thinking, sensitivity, interest in human beings and rationalism (Gok \& Erdogan, 2011, p. 32).

Creativity should not just be considered as an originality. Suitability, usefulness and feasibility are important factors distinguishing critical thinking from odd thoughts (Shalley \& Smith, 2001, p. 2). For years, creativity was attributed to genius men's mysterious thoughts and their extraordinary talents (Rubinstein, 2003, p. 696), whereas creativity does not come by birth, but is learnt in due course (Edwards, 2001, p.684; Winner, 1997, p.355).In their study, Feist-Barron (2003) argued that high-level intelligence did not guarantee high-level creativity; high-level correlation was not observed between creativity and intelligence, and an individual with high intelligence was not more creative than anyone else (adpt. Cengiz, Acuner \& Baki, 2007, p. 100). Creativity in an organisation is best when, regardless of one's position, it provides individual freedom and conditions for self-development in societal issues (Wong \& Pang, 2003, p. 551). The output of creative organisations is creative products. A creative product is extraordinary, new, suitable, useful, correct and a valuable result of an assigned task (Malaga, 2000, p. 126). There are three scales for the products in a creative organisation: coming up with as many ideas as possible for a creative task, innovation in terms of applicability and suitability of the ideas. The provisions for individual, societal and managerial organisational creativity are presented in the following paragraphs.

Researchers investigating creativity commonly agreed that creative individuals should be well informed (Carlsson, Wendt \& Risber, 2000, p. 873). Such individuals have extraordinary selections and they educate themselves (Dasgupta, 2003, p.638). Several creative individuals experience unpredictable success or failure throughout their lives (Koestner \& Walker, 1999, p. 93). However, such individuals benefit from their failures and take this as an opportunity to develop themselves (Simonton, 2000, p. 285). The future of a community is totally dependent on creative individuals with new ideas in a changing and continuously developing environment (Tennyson \& Breuer, 2002, p. 650). Motivation plays a great role in the development and effective practice of creativity (Friedman, 2002, p. 53).

Motivation is an indication of an inclination to exhibit a behaviour. Like needs emerging form internal or personal factors, external factors such as award and punishment can be sources for motivation. While motivation makes an individual an eager and effective participant in the environment, it is also needed for job satisfaction. Inspiration and motivation are the primary essence for creativity (Shalley \& Smith, 2001, p. 3). 


\subsection{The problem}

The 'Problem' refers to the evaluation of secondary school directors' organisational creativities and managerial efficiencies. The sub-problems of the Problem are as follows.

\subsubsection{Problem}

1. What technical skills are you able or unable to put into practice for school development? Why?

2. How would you evaluate your human relationships in terms of school development?

3. When you evaluate school development in terms of managerial efficiencies, what advantages do you think you can offer?

4. Do you approve proper applications in school development and appreciate success? What are these applications?

\subsection{The aim}

The aim of this research is to investigate school directors' efficiencies in organisational creativity and management through the specified sub-problems and determine the connection between managerial efficiency and organisational creativity.

\subsection{Limitations}

- This research is limited to state secondary school directors in the Turkish Republic of North Cyprus (TRNC) in the 2017-2018 academic year.

- This research focuses only on finding answers to the questions specified in the aim of the study.

\section{Methodology}

\subsection{Research method}

The research was carried out through the qualitative method, which is based on an interdisciplinary holistic view in interpreting the research question. The facts and events are interpreted in terms of people's understanding (Altinişık et al., 2010).

\subsection{The participants}

The maximum variety method, one of the purposeful sampling methods, was used in this research. The aim of this procedure is to specify common or different sides in diversities and deal with the problem in a wider detail (Buyukozturk, KilicCakmak, Akgun, Karadeniz \& Demirel, 2013; Yildirim \& Simsek, 2013). In order to pull the variety of the participants to a maximum level, gender, experience, level of teaching and type of duties were considered. All the participants were volunteer school directors or assistant directors, eight from Lefkosa, fourfrom Magusa, four from Girne and two from Guzelyurt.

\subsection{Data collection tool}

Data were collected through interview technique, in which semi-structured questions were prepared for the reliability of both directors and assistant directors as well as the study. The questions asked in a semi-structured interview were written by the researcher in advance. However, the researcher may come up with different or sub-questions in the flow of the interview to help the participant to be more precise in the answers. The semi-structured interview technique is more 
systematic and provides comparable information because it does not cover the questions previously written only (Yildirim \& Simsek, 1999).

\subsection{Data analysis}

The data were recorded on the computer and then analysed through content analysis, one of the qualitative research techniques. The main aim of content analysis is to reach concepts and connections to help the explanation of the data. In a descriptive analysis, the summarised and interpreted data go through content analysis in detail and new concepts are reached. Content analysis basically puts similar data together under certain concepts and themes and interprets them for readers' understanding. Before examining the stages of content analysis, the technical expressions need to be defined (Neuman, 2012). Similar responses given by the directors were grouped and interpreted. An expert's analysis was considered for the reliability of the study and common points were determined.

\section{Findings and discussion}

\subsection{School directors' views about the technical skills they were or were not able to put into practice in terms of school development}

$37.9 \%$ of the directors agreed on the benefits of using computers. They stated that they faced problems with regard to the internet due to frequent power cuts in the TRNC and added that the electronic boards in classrooms should be connected to the internet, which, as they emphasised, was the most important tool in school development and it provided a fast way of communication and conveying information through mailing. This view is supported by Memduhoglu (2010). The participants admitted that they could or could not practice their skills in using $20.6 \%$ of the electronic boards, $17.2 \%$ of the internet, $13.7 \%$ of the printers or I-pads and $10.3 \%$ of the virus programmes. While emphasising the importance of computer use in school development, the school directors expressed views arguing that using anti-virus programmes was less important.

\subsection{School directors' views about their skills in human relationships in school development}

$50 \%$ of the directors agreed on the effect of human-oriented approaches. They pointed to, as in companies, the importance of being human-oriented and added that the reason for that emerged from the need for teachers to express themselves better and facilitated problem-solving.

The directors also admitted that people could interact through human-oriented communication and fulfil their targets. Particularly, directors with good human-oriented relationships contributed to school and student improvement. They, as directors, said they knew the importance of trust and admitted that developing human-oriented empathy and communication facilitated their job. Their human-oriented approaches were important in mutual interaction of directors, teachers, students and the others involved within the school (Sisman, 2010).

$21.4 \%$ of the participants commented on face-to-face communication, $14.2 \%$ on information form, $7.1 \%$ on verbal communication and $7.1 \%$ on recklessness to express their skills in human relationships in terms of school development.

\subsection{Directors' views about possible advantages of managerial efficiencies in school development}

Responding the subject question above, $15 \%$ of the directors expressed positive views about approaches to organise activities. They stressed that they were helpful and fair when teachers planned to organise an activity and added that they tried to inform the public about school activities. $15 \%$ of the directors expressed views about making decisions and $15 \%$ about task distribution. 
Decision-making is a process through which the most reasonable view(s) and alternative(s) are determined to come to a sound conclusion (Sisman, 2010).

$10 \%$ of the participants expressed views about communication model, $10 \%$ about education, $10 \%$ about school councillors, $10 \%$ about positive effect, $5 \%$ about motivation, $5 \%$ about public and $5 \%$ about partners.

Communication is a social process through which people use symbols to form meanings and interpret them in their environments (West \& Turner, 2010).

The participant school directors emphasised the need for training, relating it to education theme. As for school councillor theme, the directors admitted that councillors guide the 12th grade students in their university preferences. The school councillors explained that they knew where the graduated students were and referred to the positive effect theme saying that teachers accepted their job distribution, and added that planning student development will directly affect school management.

Majority of the participant school directors failed to respond to the ways in which they can provide advantages related to education, school councillors and positive effects. As a process, management explains certain activities and studies, management as an art explains an application, and management as a science explains systematic and scientific information (Eren, 2011).

\subsection{Directors' views about appreciating success in encouraging right applications in school development}

$42.8 \%$ of the directors emphasised the effect of appreciation success by awarding plaquettes. The participant directors stated that they awarded successful teachers with plaquettes and success certificates. They admitted that such an approach was a consolidating factor in education and that they exhibited this approach. $28.5 \%$ of the participant directors advocated rewarding, $14.2 \%$ promoting to an upper position and $14.2 \%$ offer with regard to appreciating success. They stated that they awarded successful teachers and students for various achievements and pointed out that success should always be awarded for motivation. A significant number of them, on the other hand, did not raise views about the subject question. As Hoy and Misikel (2010) argue, motivation can be raised through awards, wages, appreciation and praise, and providing opportunities for carrier development.

\section{Conclusion and suggestions}

The teachers agreeing on the number of subject teachers or students in an ideal education environment expressed more positive views compared to the others.

As frequent in-service training sessions on management and creativity issues are organised, they expressed positive views. For teachers, support in encouraging them to do projects is more important than directors' efforts in preparing the teachers for psychological readiness.

The teachers expressed that priority should be in sound relationships with experts/organisations to provide suitable environments instead of receiving support from universities, research organisations, etc.

The findings in this research revealed that the directors who supported common decision-making and collaboration exhibited sufficient managerial efficiency. Physical and infrastructure shortages in secondary education cause inequality in education. The directors should know that self-development efforts will bring about satisfaction. In this regard, awarding self-development is of crucial importance.

In over-crowded schools, teacher shortages create management problems. Such schools should be specified and necessary steps should be taken. School directors should be well aware of the importance of setting measurable aims for student success and reconsidering these issues rather than talking to the teachers. 
Teacher-parent interaction in school development is of utmost importance. They should set good relationships and inform the school directors about inefficiencies.

It is assumed that creating a sound school culture and climate is of secondary importance for school directors. The reason for this should be determined. Therefore, school directors should consider and take into account common views as a platform. School directors should introduce new technologies in their schools and take necessary steps to facilitate the use of such equipment.

The concept of managerial efficiency is formed by five dimensions affecting each other. An inservice training programme in 'managerial efficiency' for directors and teachers should be considered as an urgent need. In such programmes, planning and decision-making, organisation and human resource management, teamwork, communication and leadership issues should be dealt with together.

School directors are the ones responsible for keeping the level of targets of secondary schools at a high level. Therefore, they should be given ongoing pre- and in-service training in scientific, humanitarian and conceptual skills. The Ministry of National Education should encourage arrangements and start awarding developments.

\section{References}

Altunisik, R., Coskun, R., Bayraktaroglu, S. \& Yildirim, E. (2010). SosyalBilimlerdeArastırmaYontemleri SPSS Uygulamali (6. Baski).Sakarya, Turkey: SakaryaYayincilik.

Buyukozturk, S., KilicCakmak, E., Akgun, O. E., Karadeniz, S. \& Demirel, F. (2013). Bilimselaraştırmayontemleri. Ankara, Turkey: PegemAkademi.

Carlsson, I., Wendt, P. E. \& Risberg, J. (2000). On the neurobiology of creativity differences in frontal activitybetween high and low creative subjects. Neuropsychologia, 38(9), 873-885.

Cengiz, E., Acuner, T. \& Baki, B. (2007). OrgutselYaratıciligiBelirleyenFaktorlerArasiYapisallliskiler. DokuzEylulUniversitesiSosyalBilimlerEnstitusuDergisi, 9, 1.

Dasgupta, S. (2003). Multidisciplinary creativity: the case of Herbert A. Simon, Cognitive Science, 27(7), 683-707.

Eren, E. (2011). Yonetim ve Organizasyon: Cagdas ve KureselYaklasimlar. Istanbul, Turkey: Beta BasımYayimDagitim.

Friedman, R. S. (2002). The influence of approach and avoidance motor actions on creative cognition. Journal of Experimental Social Psychology, 38, 41-55.

Gok, B. \& Erdogan, T. (2011). SinifOgretmeniAdaylarin in Yaratici DusunmeDuzeylerive Elestirel Dusunme EgilimlerininIncelenmesi. Ankara UniversitesiEgitimBilimleriFakultesiDergisi, 44(2), 29-51.

Hoy, W. K. \& Miskel, C. G. (2012). Educational administration theory, researchand practice (Cev. Edt. SelahattinTuran). Ankara, Turkey: Nobel yayincilik.

Koestner, R. \& Walker, M., (1999). Childhood parenting experiences and adult creativity. Journal of Research in Personality, 33, 92-107.

Koray, O. \& Cil, H. (2006). Ogretmen adaylarının ogrenme stilleri ve elestireldusunmebecerileriarasındakiiliskininincelenmesi. XV. Ulusal Egitim Bilimleri Kongresi'nde sunulan bildiri. MuglaUniversitesi, Mugla, Turkey, 13-15 Eylul.

Kokturk, M. (2002). KisiselGelisim Kavramına UcFarkliYaklasim. InE. Aslan (Ed.), OrgutteKisiselGelisim. Ankara, Turkey: Nobel YayinDagitim.

Malaga R. A. (2000). The effect of stimulus modes and associative distance in individual creativity support systems. Decision Support Systems, 29, 125-141.

Memduhoglu, H. B. (2010). Yonetimde Yeni Yaklasimlar: YonetimDusuncesininEvrimiveYonetisim. Ankara, Turkey: PegemAkademi.

Neuman, W. L. (2012). Toplumsal ArastirmaYontemleri: Nicel ve Nitel Yaklasimlar I-II. Cilt(5. Basım). Istanbul, Turkey: YayinOdasi. 
Shalley, C. E. \& Smith J. E. P. (2001). Effects of social-psychological factors on creative performance: the role of informational and controlling expected evaluation and modeling experience. Organizational Behavior and Human Decision Processes, 84(1), 1-22.

Simonton, D. K. (2000). Creative development as acquired expertise: theoretical issues and an empirical test. Developmental Review, 20, 283-318.

Sisman, M. (2010). Turk egitimsistemiveokulyonetimi (3. Baski). Ankara, Turkey: Pegem A. Yay.

Tennyson, R. D. \& Breuer, K. (2002). Improving problem solving and creativity through use of complex-dynamic simulations. Computers in Human Behavior, 18, 650-668.

West, R. \& Turner, L. H. (2010). Introducing communication theory: analysis and application(4th ed.). New York: McGraw-Hill.

Wong, S. \& Pang, L. (2003). Motivators to creativity in the hotel industry, perspectives of managers and supervisors. Tourism Management, 24, 551-559.

Yenilmez, K. \& Yolcu, B. (2007). OgretmenDavranislarininYaraticiDusunme Becerilerinin GelisimineKatkisi. Manas UniversitesiSosyalBilimlerDergisi, 18, 95-105.

Yildirim, A. \& Simsek, H. (1999). Sosyal Bilimlerde Nitel ArastirmaYontemleri. Ankara, Turkey: SeckinYayinevi.

Zayif, K. (2008). Ogretmenadaylarininelestireldusunmeegilimleri (YayimlanmamisYuksekLisanstezi). Abantlzzet BaysalUniversitesi, Bolu, Turkey. 